University of Louisville

ThinkIR: The University of Louisville's Institutional Repository

Faculty Scholarship

6-13-2013

\title{
Mitochondrial energetics of benthic and pelagic Antarctic teleosts.
}

Eloy Martinez

Michael A. Menze

University of Louisville, michael.menze@louisville.edu

Joseph J. Torres

Follow this and additional works at: https://ir.library.louisville.edu/faculty

Part of the Biology Commons

\section{ThinkIR Citation}

Martinez, Eloy; Menze, Michael A.; and Torres, Joseph J., "Mitochondrial energetics of benthic and pelagic Antarctic teleosts." (2013). Faculty Scholarship. 130.

https://ir.library.louisville.edu/faculty/130

This Article is brought to you for free and open access by ThinkIR: The University of Louisville's Institutional Repository. It has been accepted for inclusion in Faculty Scholarship by an authorized administrator of ThinkIR: The University of Louisville's Institutional Repository. For more information, please contact thinkir@louisville.edu. 


\title{
Mitochondrial energetics of benthic and pelagic Antarctic teleosts
}

\author{
Eloy Martinez $\cdot$ Michael A. Menze • \\ Joseph J. Torres
}

Received: 31 October 2012 / Accepted: 30 May 2013/Published online: 13 June 2013

(C) Springer-Verlag Berlin Heidelberg 2013

\begin{abstract}
Antarctic fauna are highly adapted to the frigid waters of the Southern Ocean. This study describes the in vitro temperature sensitivity of oxygen consumption rates measured in liver mitochondria from the pelagic notothenioid Pleuragramma antarcticum between 5 and $35^{\circ} \mathrm{C}$. Oxygen fluxes were measured after the addition of millimolar levels of pyruvate, malate, succinate and glutamate (state II, LEAK) and saturating levels of ADP [state III, oxidative phosphorylation (OXPHOS)]. State III respiration significantly decreased above $18.7^{\circ} \mathrm{C}$. A comparison of the oxidative capacities among $P$. antarcticum and other notothenioids showed significant differences in state III respiration, where benthic species exhibited about $50 \%$ lower rates than P. antarcticum. In addition, state III respiration rates normalized per milligram of mitochondrial protein of $P$. antarcticum were up to eight times higher than state III rates reported in the literature for other notothenioids. The comparatively high respiration rates measured in this study may be explained by our approach, which engaged both complexes I and II under conditions of oxidative phosphorylation. State III rates of independently activated complexes I and II were found to range from 42
\end{abstract}

Communicated by H.-O. Pörtner.

Eloy Martinez and Michael A. Menze contributed equally to this work.

E. Martinez $(\bowtie)$. J. J. Torres

College of Marine Science, University of South Florida,

140 7th Ave South, Saint Petersburg, FL 33701, USA

e-mail: emartin9@mail.usf.edu

M. A. Menze ( $\square)$

Department of Biological Sciences, Eastern Illinois University,

Charleston, IL 61920, USA

e-mail: mmenze@eiu.edu to $100 \%$ of rates obtained when both complexes were activated simultaneously in the same species. The remarkable tolerance of $P$. antarcticum OXPHOS toward warmer temperatures was unexpected for an Antarctic stenotherm and may indicate that thermal sensitivity of their mitochondria is not the driving force behind their stenothermy.

\section{Introduction}

Since the separation of Antarctica from South America, and its subsequent physical isolation by the Antarctic circumpolar current 21-22 mya, Antarctic fauna have undergone major adaptive changes to tolerate low environmental temperatures (Eastman 1993). Adaptations to low temperature in Antarctic ectothermic fauna, particularly in fishes, have included a high level of stenothermy (Somero and DeVries 1967). For example, at the whole organism level, the upper incipient lethal temperature of $6{ }^{\circ} \mathrm{C}$ in the notothenioids Trematomus bernacchii, Trematomus hansoni and Trematomus borchgrevinki is a clear reflection of their stenothermal character (Somero and DeVries 1967). Recently, experiments carried out by Bilyk and DeVries $(2011,2012)$ have demonstrated that gradual acclimation of Antarctic notothenioids can increase their upper critical temperatures. This new evidence suggests that notothenioids could have a greater potential for adapting to the warming trends observed in the Western Antarctic Peninsula (Vaughan et al. 2003; Turner et al. 2005) than previously thought.

The molecular underpinnings of cold adaptation in notothenioids have received considerable attention in the past 50 years. Studies include the description of respiratory pigments (Tamburrini et al. 1997; Di Prisco et al. 1998) 
and the characterization of antifreeze glycopeptides (DeVries 1983; Nagel et al. 2011). In addition to adaptations that prevent extracellular ice nucleation, various comparative studies have investigated the level of cold adaptation of notothenioids, ranging from key enzymatic activities to whole organism oxygen consumption (Wohlschlag 1960; Torres and Somero 1988). More recently, various studies described the thermal tolerance window of the mitochondrial oxidative phosphorylation (OXPHOS) system in Antarctic teleosts. Those studies provide valuable information of the thermal tolerance of the moderately active, benthic species $T$. bernacchii (Weinstein and Somero 1998) and Lepidonotothen nudifrons (Hardewig et al. 1999a) and the less active Notothenia coriiceps (Johnston et al. 1994; Mark et al. 2012) and Notothenia rossii (Mark et al. 2012). In addition, the thermal sensitivity of ADPstimulated (state III) respiration based on Arrhenius breakpoints in temperature (ABT) of the red-blooded notothenioid Gobionotothen gibberifrons and the hemoglobinless Chaenocephalus aceratus has shown similar levels of thermal plasticity in notothenioid mitochondria (Urschel and O'Brien 2009). Weinstein and Somero (1998) found an Arrhenius breakpoint in the state III respiration rate at $20.3{ }^{\circ} \mathrm{C}$ for $T$. bernacchii liver mitochondria, several degrees higher than its upper lethal temperature of around $5{ }^{\circ} \mathrm{C}$ (Somero and DeVries 1967). Similar Arrhenius plots have been employed to describe the thermal sensitivity of OXPHOS in notothenioids, where breakpoints in state III respiration have been observed at various temperatures between 9 and $31.5{ }^{\circ} \mathrm{C}$ (Hardewig et al. 1999a; Urschel and O'Brien 2008; Mark et al. 2012).

Although interspecific differences in mitochondrial substrate preferences have been recognized (Johnston et al. 1994), only a few studies describe how substrate combinations affect OXPHOS capacity of fish mitochondria. Mark and coworkers (2012) have described how the mitochondrial complexes I and II contribute to the overall OXPHOS capacity in N. coriiceps and N. rossii. Moreover, they have shown in the notothenioids $N$. coriiceps and $N$. rossii that complex-specific contributions to the OXPHOS system are non-additive, which suggests that both complexes should be experimentally activated in order to obtain better estimates of OXPHOS capacity. Previously investigated rates of oxygen flux have used a variety of substrate combinations and inhibitors. Moyes and colleagues (1989) performed a variety of assays in which mitochondrial isolations from Cyprinus carpio were exposed to single substrate titrations. Since then, studies in notothenioids combining up to three substrates have been conducted (Weinstein and Somero 1998; Hardewig et al. 1999b; Mark et al. 2012). Recent advances in mitochondrial physiology have provided insights into the use of substrate combinations for maximally engaging electron carriers and substrate transporters for the measurements of OXPHOS capacity in mammals (Gnaiger 2010a, b).The activation of both mitochondrial complexes I and II in fish mitochondria by the simultaneous addition of millimolar levels of pyruvate, glutamate, malate and succinate has been proven useful in activating mitochondrial respiration in fishes (Cook et al. 2013). However, studies to determine whether simultaneous activation of complexes I and II increases OXPHOS capacity in notothenioids have not been performed.

The two main goals of this study were (a) to investigate the contributions of NADH-UQ oxidoreductase (Complex I) and succinate dehydrogenase (Complex II) activities to respiration rates measured under OXPHOS conditions in liver mitochondria of the benthic notothenioids Trematomus loennbergii, $N$. coriiceps and Lepidonotothen squamifrons, and (b) to compare those respiration rates to the rates found in the pelagic notothenioid Pleuragramma antarcticum and the pelagic myctophid Gymnoscopelus braueri. Furthermore, we investigated the thermal tolerance window of liver mitochondria from the Antarctic silverfish, $P$. antarcticum, to determine the thresholds in the oxidative phosphorylation system as a function of temperature.

\section{Methods}

Specimen collection

Adult specimens of $P$. antarcticum and G. braueri were collected in the upper 1000 meters of the water column of the Western Antarctic Peninsula (WAP) shelf from March 25 to April 27, 2010 aboard the RV/IB Nathaniel B. Palmer. Pelagic specimens were collected both day and night using a Multiple Opening and Closing Net and Environmental Sampling System (MOCNESS, $10 \mathrm{~m}^{2}$ mouth area) and a Tucker Trawl $\left(9 \mathrm{~m}^{2}\right.$ mouth area). Benthic specimens (L. squamifrons, T. loennbergii) were collected with a $10 \mathrm{~m}$ otter trawl. $N$. coriiceps specimens were kindly provided by Dr. Arthur DeVries. $N$. coriiceps specimens were caught in shallow water (2-3 m deep) by hook and line in the vicinity of Anvers Island (Palmer Station). Both benthic and pelagic specimens were kept in large $(\sim 2,000 \mathrm{~L})$ flow-through seawater tanks at $0{ }^{\circ} \mathrm{C}$ $\left( \pm 2{ }^{\circ} \mathrm{C}\right)$ for less than a week, with the exception of $N$. coriiceps that were held in flow-through seawater tanks for $\sim 1$ month prior to analysis and fed freshly caught Euphausia superba every 2-4 days. Specimen density varied from 3 to 20 individuals per 2,000 L tank.

Isolation of liver mitochondria

Fresh livers were excised, weighed to the nearest $0.01 \mathrm{~g}$ and processed according to Weinstein and Somero (1998), 
with minor modifications. Briefly, liver tissue from one or more individuals ( $\sim 2.0 \mathrm{~g}$ of liver tissue) was minced in an ice-cold petri dish, then homogenized in $8 \mathrm{ml}$ of a sucrosebased isolation medium ( $250 \mathrm{mM}$ sucrose, $1 \mathrm{mM}$ EGTA, $10 \mathrm{mM} \mathrm{K} \mathrm{PO}_{4}, 1 \% \mathrm{BSA}, \mathrm{pH}=7.4,5^{\circ} \mathrm{C}$ ) using an icecold Dounce homogenizer (Kontes, Vineland, $\mathrm{NJ}$ ) and 5 passes with a loose fitting pestle followed by 2 passes with a tight fitting pestle. The homogenate was distributed among $1.5-\mathrm{ml}$ centrifuge tubes and centrifuged at $650 \mathrm{~g}$ for $10 \mathrm{~min}$ at $4{ }^{\circ} \mathrm{C}$ to remove cellular debris and undisrupted tissue. The supernatant was collected and again centrifuged at $9,600 \mathrm{~g}$ for $15 \mathrm{~min}$ at $4{ }^{\circ} \mathrm{C}$ to sediment the mitochondrial fraction. Pellets were washed with isolation medium, resuspended and recollected by centrifugation at $9,600 \mathrm{~g}$ for $15 \mathrm{~min}$ at $4{ }^{\circ} \mathrm{C}$ two consecutive times. The final pellet was suspended in $300-500 \mu \mathrm{L}$ of isolation medium and stored on ice until assayed.

Thermal tolerance of $P$. antarcticum liver mitochondria

To assess the thermal sensitivity of $P$. antarcticum mitochondria, a high-resolution respirometry system was employed. This system comprises a 2.0-ml water-jacketed respirometric chamber (DW-1, Hansatech Instruments, Norfolk, England) attached to a Clark-type polarographic electrode (C-1, Hansatech Instruments, Norfolk, England). Each respirometric chamber ( 2 in total) was calibrated at the desired assay temperature in the presence of $500 \mu \mathrm{L}$ of respiration medium. At each temperature, the background signal was recorded prior to mitochondrial injection. For each run, 20-50 $\mu \mathrm{L}$ of purified mitochondria were injected into the respirometer chamber containing $500 \mu \mathrm{L}$ of a 290 mOsm potassium-based respiration medium prepared following Weinstein and Somero (1998), with minor modifications (100 mM KCl, $1 \%$ w/v BSA, $2 \mathrm{mM} \mathrm{MgCl}$, $1 \mathrm{mM}$ EGTA, $25 \mathrm{mM} \mathrm{K}_{2} \mathrm{PO}_{4}, 10 \mathrm{mM}$ Tris- $\mathrm{HCl}, \mathrm{pH}=7.5$ at $5{ }^{\circ} \mathrm{C}$ ). Oxygen consumption was monitored at assay temperatures ranging from 5 to $35^{\circ} \mathrm{C}$. Measurements at habitat temperature $\left(-2\right.$ to $\left.2{ }^{\circ} \mathrm{C}\right)$ were not possible due to instrument shortcomings. Substrate stocks were prepared according to Lemieux and Gnaiger (2010). To assess the temperature sensitivity of the OXPHOS system, the following substrates were injected consecutively to each chamber: pyruvate, malate, glutamate and succinate. Final substrate concentrations in each chamber were $5 \mathrm{mM}$ pyruvate $[P], 2 \mathrm{mM}$ malate $[M], 10 \mathrm{mM}$ glutamate $[G]$ and $10 \mathrm{mM}$ succinate $[S]$. Respiratory states were determined as described in Nicholls and Ferguson (2002). Substrateinduced respiration was recorded as state II respiration and was monitored for approximately $10 \mathrm{~min}$. After state II respiration rates stabilized, $\mathrm{ADP}-$ stimulated respiration (state III, OXPHOS) was determined after adding $2 \mathrm{mM}$ ADP (10 $\mu \mathrm{L}$ from a $100 \mathrm{mM}$ neutralized ADP stock) into the chamber. State III respiration was recorded until the rates stabilized or the chamber became anoxic. ADP concentrations of $2 \mathrm{mM}$ in the chamber were necessary due to a limiting effect in state III respiration observed with lower ADP concentrations in earlier experiments. In some runs, rates were reduced by as much as $33 \%$ with ADP concentrations of $1 \mathrm{mM}$ or less at $5{ }^{\circ} \mathrm{C}$ (data not shown).

Statistical analysis and Arrhenius breakpoint in temperature (ABT) calculations

State II and state III respiration rates were calculated from the slope in oxygen consumption in each run, and averages were calculated along with their standard error. To understand the effects of temperature on OXPHOS, Arrhenius breakpoints in temperature for state III respiration rates were calculated using a 2-phase piecewise regression (Nickerson et al. 1989), on averaged respiration rates, where least squares were calculated through 200 iterations (Sigma plot 12.3, Systat Software). Respiratory control ratios (RCR) were calculated by dividing state III respiration rates by state II respiration rates. RCR values were tested for significant differences by employing a oneway ANOVA on ranks for variable sample sizes. Significance level was set to $P<0.05$ for all data presented in this study. Complex-specific differences in state III respiration were evaluated by employing a one-way ANOVA, $P<0.05$. In addition, a two-way ANOVA $(P<0.05)$ was performed to describe the differences in state III rates observed between complexes and among species.

Oxidative capacities and complex-specific contributions to the ETS in Antarctic teleosts

To investigate the contribution of specific mitochondrial complexes to overall mitochondrial function, a variety of substrate combinations were tested following the rationale of Gnaiger (2010a). Liver samples of $T$. loennbergii, $N$. coriiceps, L. squamifrons and the myctophid G. braueri were processed as described for $P$. antarcticum. The respirometer was calibrated at $10{ }^{\circ} \mathrm{C}$ with $500 \mu \mathrm{L}$ of respiration medium, and $20-50 \mu \mathrm{L}$ of purified mitochondria was added to each chamber. Each liver sample was assayed at substrate combinations that feed electrons through NADH-UQ oxidoreductase (complex I). Each mitochondrial isolation was independently assayed for complex I employing three substrate combinations; $P+M, M+G$, $P+M+G$, at final concentrations reported previously for $P$. antarcticum. This sequence allowed us to determine any additive effects of substrates within complex I. However, no differences among these substrate combinations were observed and data were pooled for statistical purposes. Assays for succinate dehydrogenase (Complex II) activity 
were performed after the addition of $10 \mathrm{mM}$ succinate in the presence of $0.5 \mu \mathrm{M}$ rotenone. In addition, separate experiments were performed where complex I and complex II were activated with a simultaneous addition of $P+M+G+S$. To ensure a clean chamber between runs, each chamber was thoroughly washed three times with deionized water, three times with $75 \%$ ethyl alcohol and three more times with deionized water. Similar to the thermal sensitivity assay, substrate-induced respiration was recorded as state II respiration and was monitored for approximately $10 \mathrm{~min}$. After state II respiration rates stabilized, state III respiration was determined after adding $2 \mathrm{mM}$ ADP $(10 \mu \mathrm{L}$ from a $100 \mathrm{mM}$ neutralized ADP stock) into the chamber. State III respiration was recorded until rates stabilized or the chamber became anoxic.

\section{Hepatosomatic index (HSI)}

Immediately before the experiment, specimens were weighed to the nearest $0.1 \mathrm{~g}$ in order to establish an energy reserve estimate by calculating the hepatosomatic index for each species. Liver samples were blotted dry and weighed after excision to the nearest $0.01 \mathrm{~g}$. Hepatosomatic indexes were calculated by dividing total liver weight in grams by the total body mass of the specimen.

\section{Mitochondrial protein quantification}

Total protein in each sample was quantified according to Bradford (1976), using the commercially available Better Bradford Commassie Stain Assay (Thermo Scientific, Rockford, IL). Samples were diluted 20:1 in deionized water and absorption values were determined after $10 \mathrm{~min}$ incubation with a Cary 1 spectrophotometer at $20^{\circ} \mathrm{C}$ and $\lambda=595 \mathrm{~nm}$. Protein values were corrected by quantifying the concentration of BSA present in the isolation buffer and subtracting it from the total protein content in the mitochondrial isolation.

\section{Results}

Thermal tolerance in mitochondria of $P$. antarcticum

Activation of the convergent pathway of electron entry into the ubiquinone pool (Q-junction) of $P$. antarcticum was achieved by the addition of saturating ADP levels in the presence of pyruvate, malate, glutamate and succinate. The thermal response of a single mitochondrial isolation exemplifies the gradual increase in state II respiration rate observed with increasing temperature (Fig. 1). State II

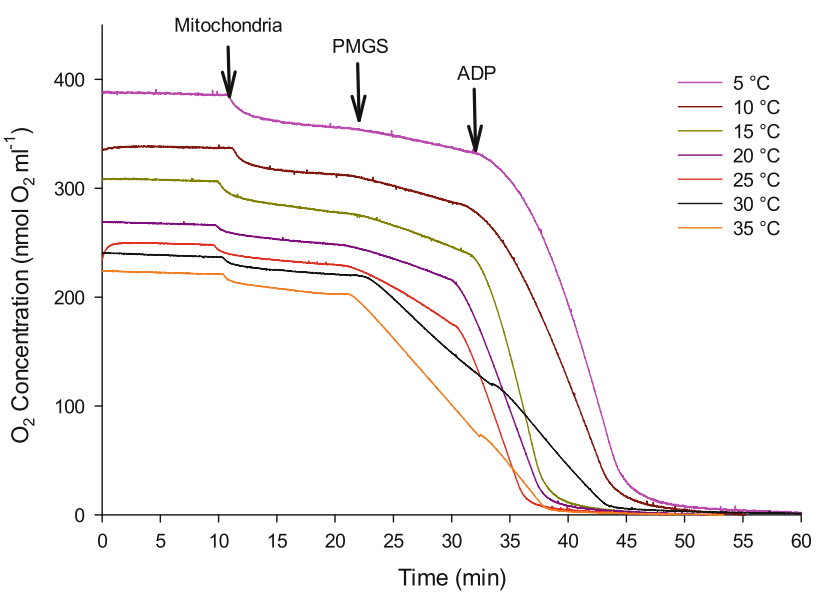

Fig. 1 Thermal sensitivity of $P$. antarcticum liver mitochondria. A representative mitochondria isolation is shown, where consecutive additions of pyruvate $(P)$, malate $(M)$, glutamate $(G)$ and succinate $(S)$ were performed. Note the changes in respiratory activities as a function of temperature

respiration rates increased tenfold from $5.99 \pm 0.37 \mathrm{nmol}$ $\mathrm{O}_{2} \min ^{-1} \mathrm{mg} \operatorname{protein}^{-1}(n=12, \pm \mathrm{SE})$ at $5{ }^{\circ} \mathrm{C}$ to $64.0 \pm 6.97 \mathrm{nmol} \mathrm{O}_{2} \min ^{-1} \mathrm{mg}$ protein ${ }^{-1}$ at $30{ }^{\circ} \mathrm{C}(n=4$, \pm SE) (Fig. 2a). Results from a two-phase regression calculation indicated an Arrhenius breakpoint for state II respiration at $16.7^{\circ} \mathrm{C}$ and the calculated $\mathrm{Q}_{10}$ for state II respiration between 5 and $15{ }^{\circ} \mathrm{C}$ was $2.63 \pm 0.22(n=8$, \pm SE).

Oxygen consumption in the presence of substrates and ADP (OXPHOS, state III) increased with temperature from 5 to $20{ }^{\circ} \mathrm{C}$ (Fig. 2b). At $5{ }^{\circ} \mathrm{C}$, state III respiration rates were lowest at $76.2 \pm 4.6(n=10, \pm \mathrm{SE}) \mathrm{nmol} \mathrm{O} \mathrm{min}^{-1}$ $\mathrm{mg}$ protein $^{-1}$. As assay temperature increased, so did the state III respiration rates, with a maximal rate registered at $20{ }^{\circ} \mathrm{C}$ of $169.9 \pm 16.0(n=8, \pm \mathrm{SE}) \mathrm{nmol} \mathrm{O}_{2} \min ^{-1} \mathrm{mg}$ protein ${ }^{-1}$. At $35^{\circ} \mathrm{C}$, the highest temperature assayed, OXPHOS rate decreased to $64.18(n=2) \mathrm{nmol} \mathrm{O}_{2} \mathrm{~min}^{-1}$ $\mathrm{mg}$ protein $^{-1}$. The two-phase regression showed a breakpoint in state III respiration rate at $18.7{ }^{\circ} \mathrm{C}$ and a calculated $\mathrm{Q}_{10}$ between 5 and $15{ }^{\circ} \mathrm{C}$ of $2.25 \pm 0.165(n=8, \pm \mathrm{SE})$. The RCR were determined at each temperature, and averages with standard error are shown (Fig. 3). The oxidation system was highly coupled with the phosphorylation system in $P$. antarcticum at temperatures of 5 and $10^{\circ} \mathrm{C}$, where RCR values reached $12.35 \pm 0.79(n=10, \pm \mathrm{SE})$ and $12.66 \pm 1.26(n=8, \pm \mathrm{SE})$, respectively (Fig. 1). These values are among the highest reported for notothenioid liver mitochondria (Hardewig et al. 1999a). No significant differences were found among RCR values obtained between 5 and $15^{\circ} \mathrm{C}$ (one-way ANOVA, $P>0.05)$. At temperatures above $15^{\circ} \mathrm{C}$, RCR values significantly decrease from $10.36 \pm 0.59(n=8, \pm \mathrm{SE})$ at 

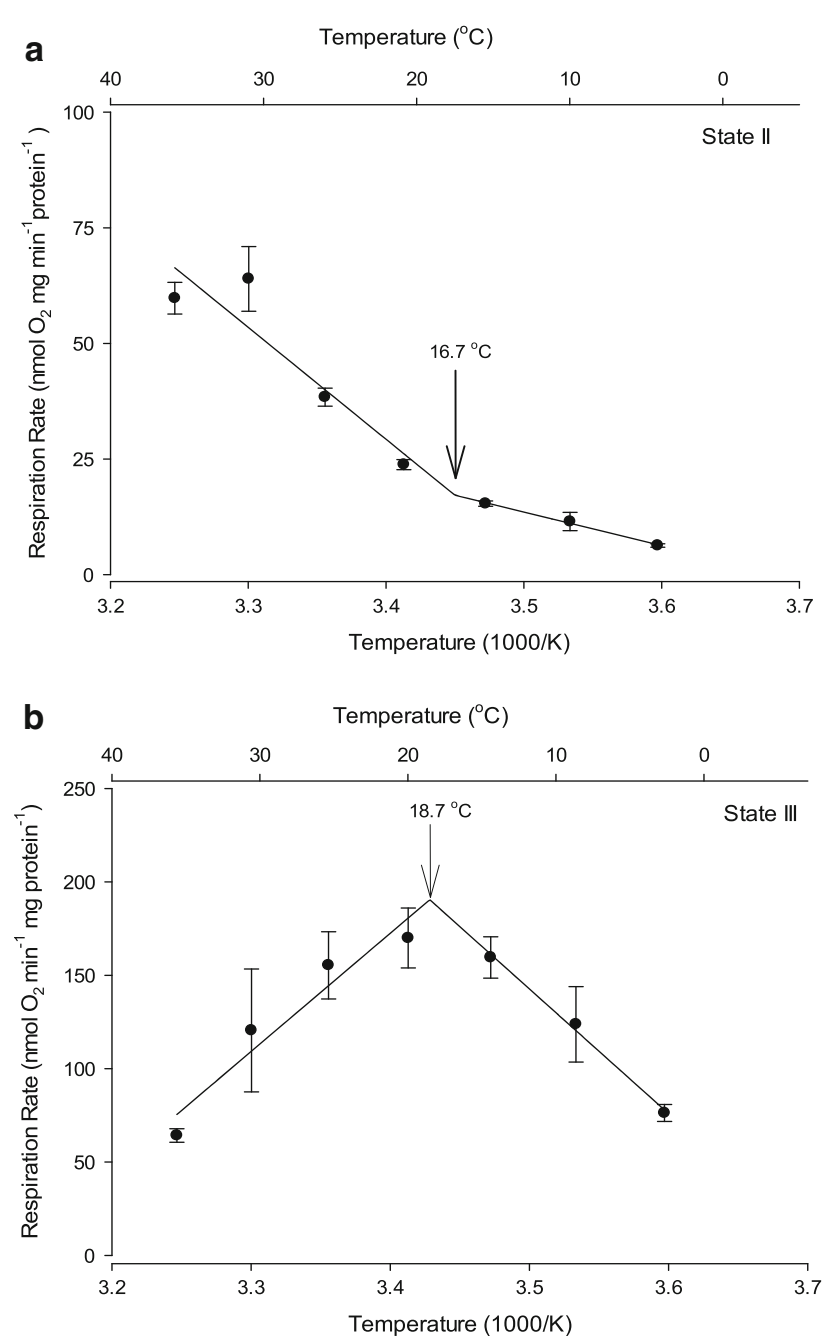

Fig. 2 a, b Respiratory states as a function of temperature for the pelagic notothenioid $P$. antarcticum. a Temperature effects on state II respiration, with a calculated Arrhenius breakpoint at $16.7^{\circ} \mathrm{C}$, where leak respiration increases as assay temperature increases. b State III respiration rates as a function of temperature. Overall state III respiration rates increase with temperature up to $15^{\circ} \mathrm{C}$, where respiration rates start to decrease after $18.7^{\circ} \mathrm{C} .(n=2-14, \pm \mathrm{SE})$. Significance level was set as $P<0.05$

$15{ }^{\circ} \mathrm{C}$ to $7.14 \pm 0.58(n=8, \pm \mathrm{SE})$ at $20{ }^{\circ} \mathrm{C}$ (one-way ANOVA, $P<0.05)$.

Oxidative capacities and complex-specific contributions to the ETS in Antarctic teleosts

Oxidative capacity of liver mitochondria at $10{ }^{\circ} \mathrm{C}$ was determined for the notothenioids $P$. antarcticum, $T$. loennbergii, $N$. coriiceps, $L$. squamifrons and the myctophid G. braueri (Table 1). Benthic notothenioids showed similar state II respiration rates when compared to their pelagic counterparts. However, state III respiration rates were twice as high in pelagic specimens when compared to the state III rates of benthic species (Mann-Whitney two-sample test,

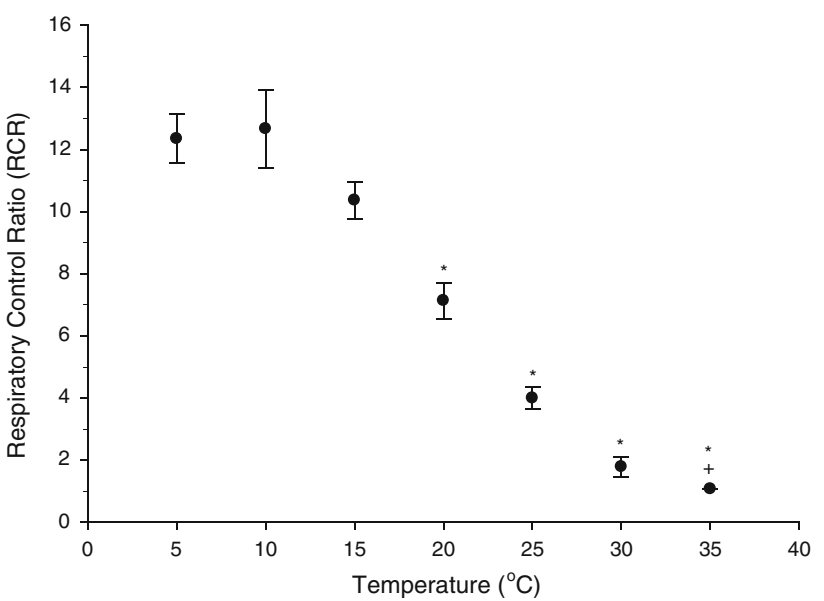

Fig. 3 Pleuragramma antarcticum respiratory control ratios at increasing temperatures. Lower temperatures are characterized by highly coupled respiration. OXPHOS efficiency decreases with increasing temperature, due to an increase in the state II respiration rates $(n=2-14, \pm$ SE). Significance level was set as $P<0.05$. (asterisks) represent significant differences from RCR at $5{ }^{\circ} \mathrm{C}$. (plus symbol) indicates $n=2$

$P<0.001)$. Respiratory control ratios calculated at $10^{\circ} \mathrm{C}$ for benthic and pelagic species ranged from 4 to 5 , with the exception of the pelagic notothenioid $P$. antarcticum, which showed lower state II respiration rates coupled with high rate increases after ADP stimulation, yielding an average respiratory control ratio of $12.66 \pm 1.26(n=8, \pm \mathrm{SE})$.

Interestingly, complex-specific state III respiration rates were strikingly different among species (Fig. 4). No significant differences were found among state III rates obtained by activating complex I with the substrate combinations $P+M, M+G$ and $P+M+G$ within each species (data not shown); thus, complex I values represent a pooled average of the aforementioned combinations. In the benthic species $N$. coriiceps, the activation of complex I by adding saturating levels of ADP in the presence NADHgenerating substrates yielded $69 \%$ of the state III respiration rate obtained with simultaneous activation of complexes I and II. On the other hand, state III respiration obtained with the activation of complex I in the pelagic $P$. antarcticum yielded $41 \%$ of state III rates obtained by simultaneous activation of complexes I and II. It was only in the species $L$. squamifrons where we found similar values of state III rates between the individually activated complexes. State III rates obtained with the simultaneous activation of both complexes elicited consistently higher rates in most species tested.

Relative contributions of complexes I and II to OXPHOS rates under convergent electron entrance into the mitochondrial ubiquinone pool varied significantly among species. By evaluating the relative contributions of complex I over complex II (Fig. 5), we can illustrate the variability of complex-specific state III respiration rates among 
Table 1 Average respiration rates $(P+M+G+S)$ at $10{ }^{\circ} \mathrm{C}$, expressed in $\mathrm{nmol} \mathrm{O}_{2} \min ^{-1} \mathrm{mg}$ protein ${ }^{-1}$

\begin{tabular}{lccc}
\hline Species & State II & State III & RCR \\
\hline Pleuragramma antarcticum $(n=12)^{\mathrm{a}}$ & $11.48 \pm 6.30$ & $144.09 \pm 53.47^{*}$ & $12.66 \pm 3.57$ \\
Gymnoscopelus braueri $(n=2)^{\mathrm{a}, \mathrm{b}}$ & 48.29 & $206.86^{*}$ & 4.28 \\
Notothenia coriiceps $(n=4)$ & $9.97 \pm 2.85$ & $50.04 \pm 13.37$ & $5.05 \pm 0.48$ \\
Lepidonothothen squamifrons $(n=4)$ & $13.84 \pm 0.36$ & $79.00 \pm 4.59$ & $5.71 \pm 0.03$ \\
Trematomus loennbergii $(n=3)$ & $15.18 \pm 2.94$ & $71.66 \pm 17.74$ & $4.78 \pm 1.24$ \\
\hline
\end{tabular}

Data show significant differences in OXPHOS capacity between benthic notothenioids and the pelagic Pleuragramma antarcticum (MannWhitney test, $P<0.001)$. State III respiration rates from $P$. antarcticum are at least two times higher than benthic counterparts

* Significant difference from state III respiration rates found in benthic species $(n=2-12, \pm \mathrm{SE})$

${ }^{a}$ Pelagic species. Significance level was set as $P<0.05$

b Due to an $n$-value below three, G. braueri was excluded from the statistical analysis

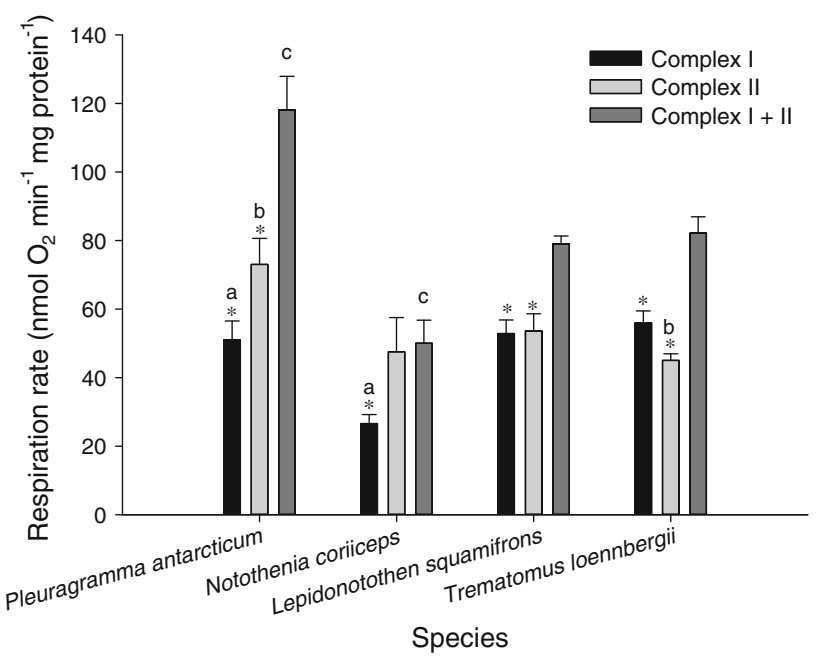

Fig. 4 Complex-specific, state III respiration rates in liver mitochondria from four Antarctic notothenioids. Complex I respiration was obtained after the addition of saturating levels of ADP in the presence of NADH-generating substrates. No difference among the three substrates combinations, pyruvate + malate, malate + glutamate or pyruvate + malate + glutamate, was found and rates were averaged. Complex II rates were obtained by the addition of saturating levels of ADP in the presence of the substrate succinate and the complex I inhibitor rotenone. Simultaneous activation of complexes I and II was achieved by adding saturating levels of ADP to the chamber containing the substrates pyruvate, malate, glutamate and succinate $(n=4-12, \pm \mathrm{SE})$.Values with an asterisk are significantly different from the rates obtained when both complexes were activated in the same species (one-way ANOVA, $P<0.05)$. Letters $(a-c)$ indicate statistically significant differences in individual, complex-specific rates among species (two-way ANOVA, $P<0.05$ )

notothenioids. Similar contributions between complex I and complex II were found in L. squamifrons and T. loennbergii, where the average complex I-to-complex II ratios were $0.82 \pm 0.04$ and $0.87 \pm 0.02(n=4, \pm \mathrm{SE})$, respectively. The highest complex I contribution in state III was found in the pelagic species $G$. braueri, with a C-I/C-II ratio of $\sim 1.62(n=2)$. The highest contribution of complex II was found in $N$. coriiceps, where the relative

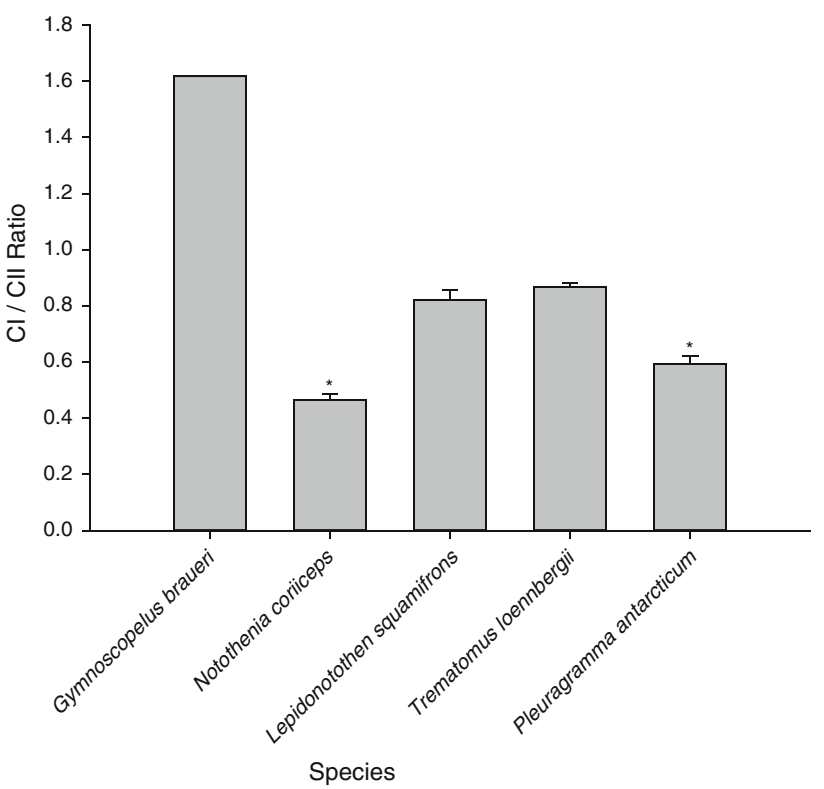

Fig. 5 Complex I/complex II ratio of state III respiration in liver mitochondria of Antarctic teleosts, measured independently in the presence of NADH-generating substrates (complex I) and in the presence of succinate and the complex I inhibitor rotenone $(n=4$, $\pm \mathrm{SE})$. G. braueri was excluded from statistical analysis due to low sample size $(n=2)$. Ratios among species were variable, and statistically significant differences from all other species are indicated by an asterisk (one-way ANOVA, $P<0.05$ )

contribution of complex I over complex II was $0.46 \pm 0.02$ $(n=4, \pm \mathrm{SE})$.

Hepatosomatic index

Hepatosomatic indexes are summarized in Table 2. Average HSI was variable among species, with $T$. loennbergii displaying the highest HSI obtained of $0.023 \pm 0.01$ $(n=3, \pm \mathrm{SE})$. HSI's in pelagic specimens ranged from $0.0186(n=2) \quad$ in the myctophid $G$. braueri, to $0.011 \pm 0.003$ in $P$. antarcticum. 
Table 2 Body mass range and hepatosomatic index (HSI) of Antarctic fish species

\begin{tabular}{lcc}
\hline Species & Body mass range $(\mathrm{g})$ & Mean HSI $( \pm$ SE) \\
\hline Pleuragramma antarcticum $(n=12)$ & $16.2-54.9$ & $0.0108 \pm 0.003$ \\
Gymnoscopelus braueri $(n=2)$ & $37.4-43.0$ & 0.0186 \\
Notothenia coriiceps $(n=4)$ & $732.1-830.8$ & $0.0116 \pm 0.001$ \\
Lepidonothothen squamifrons $(n=4)$ & $92.2-160.4$ & $0.0153 \pm 0.005$ \\
Trematomus loennbergii $(n=3)$ & $108.3-138.6$ & $0.0235 \pm 0.005$ \\
\hline
\end{tabular}

HSI was calculated as the ratio of liver weight to body weight. It provides an indication on the status of energy reserve of the specimens collected in this study. HSI variability is expressed as standard error

\section{Discussion}

\section{Thermal tolerance in $P$. antarcticum}

The effects of temperature on the ETS and more globally on the OXHPOS system were characterized in detail for $P$. antarcticum. State II respiration rates obtained by activating complexes I and II with pyruvate, malate, glutamate and succinate were found to increase with assay temperature, with an observable break at $16.7^{\circ} \mathrm{C}$ in the Arrhenius plot (Fig. 2). At temperatures above $15^{\circ} \mathrm{C}$, state II respiration rates increased significantly, which resulted in decreasing RCR values. Although the state II breakpoint does not correspond to a transition from positive to negative slope values as found by Weinstein and Somero (1998), it constitutes a breakpoint at which state II respiration increases significantly. Higher LEAK respiration rates at increasing temperature are associated with the loss of membrane integrity at these temperatures (Hazel 1995; Hochachka and Somero 2002), which cause a higher proton leak across the inner membrane to the mitochondrial matrix. Moreover, recent findings by Mark et al. (2012) indicate a loss of membrane potential during state II over a similar temperature range $\left(0-15{ }^{\circ} \mathrm{C}\right)$ in $N$. coriiceps. This finding is in accordance with our interpretation that the increase in state II respiration observed in $P$. antarcticum may be attributed to an increase in proton permeability of the inner mitochondrial membrane, rather than a decrease in the complex-specific activities.

We found that the calculated Arrhenius breakpoint temperature (ABT) in state III respiration in $P$. antarcticum is low $\left(18.7{ }^{\circ} \mathrm{C}\right)$, compared to a state III ABT of $35^{\circ} \mathrm{C}$ in the tropical teleost Sarotheridon mossambica (Weinstein and Somero 1998). However, results obtained for P. antarcticum were found to be similar to the ABT found for the benthic notothenioid $T$. bernacchii of $20.3{ }^{\circ} \mathrm{C}$ by Weinstein and Somero (1998). Despite the similarities between state III ABT between $P$. antarcticum and $T$. bernacchii, Mark et al. (2012) found state III ABT's to be between 6 and $9{ }^{\circ} \mathrm{C}$ in $N$. coriiceps and $N$. rossii, a significant contrast to those ABT's found elsewhere for notothenioids. This remarkable level of variation of the thermal sensitivity of coupled respiration among species could be attributed to a number of factors including the tissue type (e.g., red muscle, cardiac muscle, liver) and the isolation method. A recent study by Urschel and O'Brien (2009) has found higher $\left(28.7-31.5^{\circ} \mathrm{C}\right)$ state III ABT for mitochondria isolated from heart ventricles of the notothenioids $G$. gibberifrons, Chionodraco rastrospinosus and C. aceratus. High coupling was achieved by utilizing a respiration assay medium with an osmolarity of $435 \mathrm{mOsm}$, which comes close to the blood osmolarity of the specimens assayed. Moreover, this and other studies point toward the effect of a hypoosmotic respiration medium in the ABT. Buffer osmolarities lower than the blood osmotic concentration could reduce state III respiration rates in fish mitochondria (Ballantyne and Moon 1986; Urschel and O'Brien 2009). Further work on the effects of medium osmolarity should be conducted in various tissue types to confirm this finding, as high coupling at higher osmolarities has been confirmed only for notothenioid cardiac tissue (Urschel and O'Brien 2009).

LEAK respiration rates observed when both complexes I and II were activated at temperatures below ABT only constitute about $10 \%$ of state III rates obtained at the same temperature (Fig. 2). This value is small compared to about $50 \%$ of state III with only complex I activated in snapper mitochondria (Cook et al. 2013) and slightly lower than $15 \%$ of state III found in permeabilized heart ventricle fibers of triplefin blennies at $15{ }^{\circ} \mathrm{C}$ (Hilton et al. 2010). However, similar values have been obtained for the notothenioid $L$. nudifrons $\left(10.2 \%\right.$ at $\left.0{ }^{\circ} \mathrm{C}\right)$, which suggest a low proton leakiness of the inner mitochondrial membrane in notothenioids (Hardewig et al. 1999a). Respiration rates obtained with ADP and uncoupled rates after FCCP additions showed that state III respiration can be up to $89 \%$ of the maximum respiratory capacity (data not shown), suggesting that coupled respiration is operating at maximal or close to maximal capacity. These results suggest that the loss of performance observed at temperatures warmer than ABT could be explained by changes in membrane fluidity (Hazel 1995), in addition to a possible decrease in the activity of key enzyme complexes involved in the ETS due to the hindering effects of heat on hydrophobic interactions 
between the inner membrane and the enzyme complexes involved (O'Brien et al. 1991). However, at temperatures lower than ABT, we favor an increase in membrane permeability as a driving factor for the increase in state II respiration rates. These drastic differences in state II observed both above and below ABT could also be attributed to an increasing $\mathrm{Q}_{10}$ or further activation of uncoupling proteins (UCP) at warmer temperatures (Mark et al. 2006). However, UCP activation should not have been a major contributor to state II rates in our systems due to the addition of high concentrations of BSA $(10.0 \mathrm{~g} / \mathrm{L}$ BSA), which keeps free fatty acid levels low. There are several advantages for the expression of the UCP2, which includes the role of 'safety valve,' preventing the formation of reactive oxygen species under oxidative stress (Skulachev 1998). Although Hardewig and coworkers (1999a) have suggested an enzyme-mediated leak respiration in L. nudifrons due to a high $\mathrm{Q}_{10}$ value for state II respiration rates, additional work will be necessary to further confirm this hypothesis.

Average state III respiration rates declined as assay temperature rose above $15{ }^{\circ} \mathrm{C}$, with a calculated $\mathrm{ABT}$ in state III respiration of about $18.7^{\circ} \mathrm{C}$ (Fig. 2). Decreasing mitochondrial ATP-coupled respiration with increasing temperatures could be attributed to the disruption of hydrophobic interactions between membrane-bound enzymes and the inner membrane (O'Brien et al. 1991), specifically the enzymes complexes I and II, along with the $F_{1} F_{0}$-ATPase. These weak-bond interactions between enzymes and their associated membranes, or among protein subunits, are central to maintaining the catalytic function of enzymes (Hochachka and Somero 1973). Therefore, it is plausible that the observed reduction in state III respiration with increasing temperature may be related to alterations of hydrophobic interactions between membrane lipids and the transmembrane $\alpha$-helices comprising the $F_{0}$-region, affecting its proton conductance (Nicholls and Ferguson 2002).

Oxidative capacities and complex-specific contributions to the ETS in Antarctic teleosts

Additive effects of substrates on ETS activity were evaluated for a series of notothenioids and a pelagic myctophid. State II respiration rates obtained with the activation of complex I were similar among species. Substrate combinations enabling NADH supply to complex I $(P+M$, $M+G, P+M+G)$ elicited similar state II rates, resulting in less than $50 \%$ of the state II rates obtained with simultaneous electron entry via NADH and $\mathrm{FADH}_{2}$ $(P+M+G+S)$. Only $P$. antarcticum samples showed a complex I-specific leak respiration of close to $70 \%$ of the state II rate obtained with both complexes activated.
Electron supply to the ETS via complex II alone by the sole addition of succinate and rotenone yielded similar state II rates as those obtained with the addition of PMGS (data not shown). These findings suggest a high contribution of electrons from complex II to the Q-junction, or a complex II-specific higher proton leak in the species studied. Although we were unable to measure the mitochondrial membrane potential in our study, it was found by Mark et al. (2012) that complex-specific activation can result in significant differences in membrane potential. Therefore, complex-dependent differences in the mitochondrial membrane potential due to independent activations of complex I and complex II may contribute to the variability in LEAK respiration rates observed in our study.

State III respiration rates obtained by activating individual complexes were variable among species (Fig. 4). Complex-specific variability among species has also been documented in two other notothenioids (Mark et al. 2012), but the state III rates reported for $N$. coriiceps in our study are significantly higher than those found by Mark and coworkers (2012). In addition, our values are in close agreement with the variation in complex-specific contributions found in triplefin blennies (Hilton et al. 2010). Furthermore, complex-specific state III rates in Fig. 4 demonstrate that PMGS titration yields consistently higher estimates of state III respiration rates in a variety of species. In previous studies, the use of individual substrates to understand substrate preferences resulted in the use of pyruvate as the major substrate in similar assays (Moyes et al. 1989, 1992; Johnston et al. 1994). More recent studies utilized titrations including PM to activate complex I and PMS to activate both complexes I and II, and others have used rotenone as a complex I inhibitor in the presence of S to activate solely complex II (Weinstein and Somero 1998; Hardewig et al. 1999a; Lannig et al. 2005). The addition of glutamate and the overall combination of PMGS in a single run has been utilized in snappers recently (Cook et al. 2013), and our study constitutes the first attempt in notothenioids. Recent studies on human muscle mitochondria showed additive effects of those substrates, mainly due to the convergent nature of the ETS (Gnaiger 2009). Any increase in respiration rates observed with glutamate addition to the substrate cocktail may be explained by its participation in the malate-aspartate shuttle, which includes a glutamate-aspartate carrier and 2-oxoglutarate (Gnaiger 2010a). This process provides additional 2-oxoglutarate and $\mathrm{NADH}$, increasing the reducing power of the ETS.

As shown in Table 3, maximal OXPHOS activity expressed as state III respiration was similar to that found in the literature for benthic specimens. When extrapolated to $0{ }^{\circ} \mathrm{C}, N$. coriiceps liver mitochondria exhibited lower state III rates than observed in red muscle tissue of $N$. coriiceps 
Table 3 Maximal values of ADP-induced state III respiration reported for Antarctic teleosts in the literature and this study

\begin{tabular}{|c|c|c|c|c|c|c|c|c|}
\hline Species & Lifestyle & $\begin{array}{l}\text { Tissue } \\
\text { type }\end{array}$ & $\begin{array}{l}\text { Assay } \\
\text { temp } \\
\left({ }^{\circ} \mathrm{C}\right)\end{array}$ & $\begin{array}{l}\text { Substrate/ } \\
\text { concentration } \\
(\mathrm{mM})\end{array}$ & $\begin{array}{l}\text { Max rate }\left(\text { nmol } \mathrm{O}_{2}\right. \\
\left.\min ^{-1} \mathrm{mg} \mathrm{protein}^{-1}\right)\end{array}$ & $\mathrm{Q}_{10}$ & $\begin{array}{l}\text { Estimated } \\
\text { rate at } 0{ }^{\circ} \mathrm{C}\end{array}$ & Source \\
\hline $\begin{array}{l}\text { Lepidonotothen } \\
\text { nudifrons }\end{array}$ & Benthopelagic & Liver & 0 & Succinate/3.3 & 7.36 & 2.43 & 7.36 & $\begin{array}{l}\text { Hardewig et al. } \\
(1999 a, 1999 b)\end{array}$ \\
\hline $\begin{array}{r}\text { Notothenia } \\
\text { coriiceps }\end{array}$ & Benthic & $\begin{array}{l}\text { Red } \\
\text { muscle }\end{array}$ & -1.0 & $\begin{array}{l}\text { Pyruvate/2.5 } \\
\text { Malate/0.1 }\end{array}$ & 31.0 & 1.90 & 31.6 & $\begin{array}{l}\text { Johnston et al. } \\
\text { (1994) }\end{array}$ \\
\hline $\begin{array}{r}\text { Notothenia } \\
\text { coriiceps }\end{array}$ & Benthic & Liver & 3.0 & $\begin{array}{l}\text { Malate/1.0 } \\
\text { Glutamate/1.3 }\end{array}$ & 9.0 & 2.60 & 7.02 & $\begin{array}{l}\text { Mark et al. } \\
\text { (2012) }\end{array}$ \\
\hline $\begin{array}{l}\text { Notothenia } \\
\text { rossii }\end{array}$ & Benthic & Liver & 3.0 & $\begin{array}{l}\text { Malate/1.0 } \\
\text { Glutamate/1.3 }\end{array}$ & 4.4 & 1.71 & 2.26 & $\begin{array}{l}\text { Mark et al. } \\
\text { (2012) }\end{array}$ \\
\hline $\begin{array}{r}\text { Notothenia } \\
\text { coriiceps }\end{array}$ & Benthic & Liver & 10.0 & $\begin{array}{l}\text { Pyruvate/5.0 } \\
\text { Malate/2.0 } \\
\text { Glutamate/10.0 } \\
\text { Succinate/10.0 }\end{array}$ & 50.04 & $1.9 *$ & 26.34 & Present Study \\
\hline $\begin{array}{l}\text { Pleuragramma } \\
\text { antarcticum }\end{array}$ & Pelagic & Liver & 5.0 & $\begin{array}{l}\text { Pyruvate/5.0 } \\
\text { Malate/2.0 } \\
\text { Glutamate/10.0 } \\
\text { Succinate/10.0 }\end{array}$ & 76.23 & 2.25 & 55.06 & Present Study \\
\hline $\begin{array}{l}\text { Pleuragramma } \\
\text { antarcticum }\end{array}$ & Pelagic & Liver & 10.0 & $\begin{array}{l}\text { Pyruvate/5.0 } \\
\text { Malate/2.0 } \\
\text { Glutamate/10.0 } \\
\text { Succinate/10.0 }\end{array}$ & 123.73 & 2.25 & 54.99 & Present Study \\
\hline $\begin{array}{l}\text { Lepidonotothen } \\
\text { squamifrons }\end{array}$ & Benthopelagic & Liver & 10.0 & $\begin{array}{l}\text { Pyruvate/5.0 } \\
\text { Malate/2.0 } \\
\text { Glutamate/10.0 } \\
\text { Succinate/10.0 }\end{array}$ & 79.00 & $2.43^{\mathrm{a}}$ & 32.51 & Present Study \\
\hline $\begin{array}{l}\text { Gymnoscopelus } \\
\text { braueri }\end{array}$ & Pelagic & Liver & 10.0 & $\begin{array}{l}\text { Pyruvate/5.0 } \\
\text { Malate/2.0 } \\
\text { Glutamate/10.0 } \\
\text { Succinate/10.0 }\end{array}$ & 206.86 & $2.0^{*}$ & 103.43 & Present Study \\
\hline $\begin{array}{l}\text { Trematomus } \\
\quad \text { loennbergii }\end{array}$ & Benthopelagic & Liver & 10.0 & $\begin{array}{l}\text { Pyruvate/5.0 } \\
\text { Malate/2.0 } \\
\text { Glutamate/10.0 } \\
\text { Succinate/10.0 }\end{array}$ & 71.66 & $2.43^{\mathrm{a}}$ & 29.49 & Present Study \\
\hline
\end{tabular}

Only studies that utilized mitochondrial protein for rate standardization are shown

$\mathrm{Q}_{10}$ with an asterisk represents an estimated value

${ }^{a}$ Data were standardized to rates at $0{ }^{\circ} \mathrm{C}$ for comparative purposes by using reported $\mathrm{Q}_{10}$ values for $L$. nudifrons (Hardewig et al. 1999a, b)

and livers mitochondria of other notothenioids (Johnston et al. 1994, 1998; Mark et al. 2012). However, state III rates of the conspecifics $L$. squamifrons and L. nudifrons (Hardewig et al. 1999a) were found to be significantly different. These differences were expected due to differences in the titration protocol: Values for $L$. nudifrons corresponded to state III rates in the presence of only succinate, ADP and the complex I inhibitor rotenone. By looking at the complex-specific contributions to the OXPHOS rate (Fig. 5), it was possible to elucidate how complex-specific respiration rates vary within a species and how these differences were reflected in the species' OXPHOS capacity. Complex-specific, state III respiration rates found in this study (see Fig. 5) agreed well with the findings by Mark et al. (2012), where complex I contributions ranged from 40 to $50 \%$ of complex II, to about $60-100 \%$ in $N$. coriiceps and $N$. rossii, respectively. Similar values have been obtained for triplefin blennies (Hilton et al. 2010), suggesting an intrinsic variability of state III respiration rates with $\mathrm{FADH}_{2}$ or NADH-generating substrates.

When state III respiration rates were compared with those found elsewhere, the pelagic P. antarcticum displayed 
state III respiration rates well above those documented for Antarctic notothenioid liver mitochondria (Weinstein and Somero 1998; Hardewig et al. 1999a). As shown in Table 1, $P$. antarcticum exhibited twice the state III respiration rates of its benthic counterparts. Citrate synthase activity measured for G. braueri, T. loennbergii, T. bernacchii (Torres and Somero 1988) and P. antarcticum (Martinez and Torres, in preparation) indicated that the observed high state III respiration rates were not related to significant differences in the expression of enzymes associated with the citric acid cycle. However, the observation does not exclude the possibility of an increase in enzyme activity by allosteric activation or phosphorylation under our assay conditions, nor does it exclude a possible increase in the activity levels of other enzymes involved in the citric acid cycle.

One plausible explanation among others for the higher state III respiration rates in $P$. antarcticum is a higher utilization of lipid in its overall metabolic strategy through $\beta$-oxidation of fatty acids. Lipid metabolism is known to occur in the liver, where mitochondria are able to metabolize fatty acids under appropriate conditions (Middleton 1978). In general, fatty acid metabolism involves the cytosolic activation of fatty acids before they are transported into the mitochondrial matrix. High concentrations of malonyl coenzyme $A$ in the absence of free fatty acids could provide additional coenzyme A to increase the formation of citrate in the presence of pyruvate. This has been shown in rat soleus muscle, where additions of glucose to skeletal muscle incubations in the presence of insulin increases the level of malonyl CoA, as well as the levels of citrate and malate (Saha et al. 1997). Large quantities of adipocytes found in P. antarcticum (DeVries and Eastman 1978; Eastman and DeVries 1989) could point toward an enhanced citric acid cycle in lipid-rich liver tissue from $P$. antarcticum. In summary, we consider that the large difference in state III observed between $P$. antarcticum and benthic notothenioids at $10{ }^{\circ} \mathrm{C}$ could be attributed to varying levels of coenzyme A, which increases cytosolic citrate in the presence of pyruvate, increasing the reducing power of the citric acid cycle. However, this has yet to be experimentally confirmed and a comparative analysis of coenzyme A values among species would be instructive.

Acknowledgments The authors of this manuscript would like to thank all crew members and members of the science party aboard the RV/IB Nathaniel B. Palmer (Cruise B-258-N) who assisted in the specimen collection. We would also like to thank Dr. Arthur L. DeVries for providing $N$. coriiceps specimens. This project was funded by NSF-0741348 awarded to Dr. Joseph J. Torres.

\section{References}

Ballantyne J, Moon T (1986) Solute effects on mitochondria from an elasmobranch Raja erinacea and a teleost Pseudopleuronectes americanus. J Exp Zool 239:319-328
Bilyk KT, DeVries AL (2011) Heat tolerance and its plasticity in Antarctic fishes. Comp Biochem Physiol A: Mol Integr Physiol 158:382-390

Bilyk KT, Devries AL (2012) Heat tolerance of the secondarily temperate Antarctic notothenioid, Notothenia angustata. Antarct Sci 24:1-8

Bradford MM (1976) A rapid and sensitive method for the quantitation of microgram quantities of protein utilizing the principle of protein-dye binding. Anal Biochem 72:248-254

Cook DG, Iftikar FI, Baker DW, Hickey AJR, Herbert NA (2013) Low- $\mathrm{O}_{2}$ acclimation shifts the hypoxia avoidance behaviour of snapper Pagrus auratus with only subtle changes in aerobic and anaerobic function. J Exp Biol 216:369-378

DeVries AL (1983) Antifreeze peptides and glycopeptides in coldwater fishes. Annu Rev Physiol 45:245-260. doi:10.1146/ annurev.ph.45.030183.001333

DeVries AL, Eastman JT (1978) Lipid sacs as a buoyancy adaptation in an Antarctic fish. Nature 271:352-353

Di Prisco G, Tamburrini M, D’Avino R (1998) Oxygen-transport systems in extreme environments: multiplicity and structure/ function relationship in hemoglobins of Antarctic fish. In: Pörtner HO, Playle RC (eds) Cold ocean physiology. Cambridge University Press, Cambridge, pp 143-165

Eastman J (1993) Antarctic fish biology: evolution in a unique environment. Academic Press, San Diego, p 322

Eastman J, DeVries A (1989) Ultrastructure of the lipid sac wall in the Antarctic notothenioid fish Pleuragramma antarcticum. Polar Biol 9:333-335

Gnaiger E (2009) Capacity of oxidative phosphorylation in human skeletal muscle: new perspectives of mitochondrial physiology. Int J Biochem Cell Biol 41:1837-1845

Gnaiger E (2010a) Mitochondrial pathways through complexes I + II: convergent electron transfer at the Q-junction and additive effect of substrate combinations. pp 1-13 (MiPNet 12.12)

Gnaiger E (2010b) Mitochondrial pathways to complex I: respiration with pyruvate, glutamate and malate. pp 1-9 (MiPNet 11.04)

Hardewig I, Pörtner H, Peck L (1999a) Thermal sensitivity of mitochondrial function in the Antarctic Notothenioid Lepidonotothen nudifrons. J Comp Physiol B Biochem Syst Environ Physiol 169:597-604

Hardewig I, van Dijk PL, Moyes CD, Pörtner HO (1999b) Temperature-dependent expression of cytochrome-c oxidase in Antarctic and temperate fish. Am J Physiol Regul Integr Comp Physiol 277:R508-R516

Hazel J (1995) Thermal adaptation in biological membranes: is homeoviscous adaptation the explanation? Annu Rev Physiol $57: 19-42$

Hilton Z, Clements KD, Hickey AJR (2010) Temperature sensitivity of cardiac mitochondria in intertidal and subtidal triplefin fishes. J Comp Physiol B Biochem Syst Environ Physiol 180:979-990

Hochachka PW, Somero GN (1973) Strategies of biochemical adaptation. W. B. Saunders, Philadelphia

Hochachka PW, Somero GN (2002) Biochemical adaptation: mechanism and process in physiologica evolution. Oxford University Press, New York

Johnston I, Guderley H, Franklin C, Crockford T, Kamunde C (1994) Are mitochondria subject to evolutionary temperature adaptation? J Exp Biol 195:293-306

Johnston I, Calvo J, Guderley YH (1998) Latitudinal variation in the abundance and oxidative capacities of muscle mitochondria in perciform fishes. J Exp Biol 201:1-12

Lannig G, Storch D, Pörtner H (2005) Aerobic mitochondrial capacities in Antarctic and temperate eelpout (Zoarcidae) subjected to warm versus cold acclimation. Polar Biol 28: $575-584$ 
Lemieux H, Gnaiger E (2010) Oxygraph-2 k manual titrations: mitochondria, permeabilized cells, and biopsies. p 1 (MiPNet 09.12)

Mark FC, Lucassen M, Strobel A, Barrera-Oro E, Koschnick N, Zane L, Patarnello T, Pörtner HO, Papetti C (2012) Mitochondrial function in Antarctic Nototheniids with ND6 translocation. PLoS ONE 7:e31860

Middleton B (1978) Enzymatic aspects of ketone body metabolism: the role of mitochondrial acetoacetyl-CoA thiolase isoenzymes. In: Soling HD, Senfert C (eds) Biochemical and clinical aspects of ketone body metabolism. Georg Thieme Verlag, Stuttgart, pp $1-10$

Moyes C, Buck L, Hochachka P, Suarez R (1989) Oxidative properties of carp red and white muscle. J Exp Biol 143:321-331

Moyes CD, Mathieu-Costello OA, Brill RW, Hochachka PW (1992) Mitochondrial metabolism of cardiac and skeletal muscles from a fast Katsuwonus pelamis and a slow Cyprinus carpio fish. Can J Zool 70:1246-1253

Nagel L, Plattner C, Budke C, Majer Z, DeVries AL, Berkemeier T, Koop T, Sewald N (2011) Synthesis and characterization of natural and modified antifreeze glycopeptides: glycosylated foldamers. Amino Acids 41:719-732

Nicholls DG, Ferguson SJ (2002) Bioenergetics. Academic Press, San Diego

Nickerson DM, Facey DE, Grossman GD (1989) Estimating physiological thresholds with continuous two-phase regression. Physiol Zool 62:866-887

O'Brien J, Dahlhoff E, Somero GN (1991) Thermal resistance of mitochondrial respiration: hydrophobic interactions of membrane proteins may limit thermal resistance. Physiol Zool 64:1509-1526

Saha A, Vavvas D, Kurowski T, Apazidis A, Witters L, Shafrir E, Ruderman N (1997) Malonyl-CoA regulation in skeletal muscle: its link to cell citrate and the glucose-fatty acid cycle. Am J Physiol Endocrinol Metab 272:E641-E648

Skulachev VP (1998) Uncoupling: new approaches to an old problem of bioenergetics. Biochim Biophys Acta 1363:100-124

Somero GN, DeVries AL (1967) Temperature tolerance of some Antarctic fishes. Science 156:257-258

Tamburrini M, D'avino R, Carratore V, Kunzmann A, Di Prisco G (1997) The hemoglobin system of Pleuragramma antarcticum: correlation of hematological and biochemical adaptations with life style. Comp Biochem Physiol A Physiol 118:1037

Torres J, Somero G (1988) Metabolism, enzymic activities and cold adaptation in Antarctic mesopelagic fishes. Mar Biol 98:169-180

Turner J, Colwell SR, Marshall GJ, Lachlan-Cope TA, Carleton AM, Jones PD, Lagun V, Reid PA, Iagovkina S (2005) Antarctic climate change during the last 50 years. Int $\mathrm{J}$ Climatol 25:279-294

Urschel MR, O'Brien KM (2009) Mitochondrial function in Antarctic notothenioid fishes that differ in the expression of oxygenbinding proteins. Polar Biol 32:1323-1330

Urschel M, O'Brien K (2008) High mitochondrial densities in the hearts of Antarctic icefishes are maintained by an increase in mitochondrial size rather than mitochondrial biogenesis. J Exp Biol 211:2638

Vaughan DG, Marshall GJ, Connolley WM, Parkinson C, Mulvaney R, Hodgson DA, King JC, Pudsey CJ, Turner J (2003) Recent rapid regional climate warming on the Antarctic Peninsula. Clim Change 60:243-274

Weinstein R, Somero G (1998) Effects of temperature on mitochondrial function in the Antarctic fish Trematomus bernacchii. J Comp Physiol B Biochem Syst Environ Physiol 168:190-196

Wohlschlag DE (1960) Metabolism of an Antarctic fish and the phenomenon of cold adaptation. Ecology 41:287-292 